\title{
Enteroparasite contamination in peridomiciliar soils of two indigenous territories, State of Paraná, southern Brazil
}

\author{
Fabiana de Toledo Moura, ${ }^{1}$ Dina Lúcia Moraes Falavigna, ${ }^{1}$ \\ Lúcio Tadeu Mota, ${ }^{2}$ and Max Jean de Ornelas Toledo ${ }^{1}$
}

Suggested citation

Moura FT, Falavigna DLM, Mota LT, Toledo MJO. Enteroparasite contamination in peridomiciliar soils of two indigenous territories, State of Paraná, southern Brazil. Rev Panam Salud Publica. 2010;27(6): $414-22$.

ABSTRACT Objectives. To determine 1) the degree of soil contamination by parasites; 2) the prevalence of contaminated samples; 3 ) the overall number of parasitic forms, by distance between the collection site and the domicile; 4) the mean number of parasite forms per peri-household area; and 5) the variables associated with the total number of parasite forms.

Methods. Soil samples were collected in the peridomicile of 18 (out of a total sample of 63) and 22 (out of 190) residences of the Faxinal and Ivaí indigenous territories (ITs), respectively, from March 2005 through October 2006, and evaluated by the methods of Baermann, modified Faust et al., and Lutz.

Results. The overall prevalence of samples contaminated by enteroparasites of humans or of animals with zoonotic potential was 75.7\% (84 out of 111) in Faxinal and 96.2\% (127 out of 132) in Ivaí. The most prevalent parasites were Ascaris spp., Isospora spp., and Toxocara spp. Positive statistical associations were observed between the number of parasitic forms per domicile and the following variables: time of year (season), the presence of bathrooms in the domicile, and the presence of excrement on peridomiciliar soil.

Conclusions. The high level of soil contamination in Faxinal and Ivaí 1) constitutes a potential source of parasitic infection and 2) suggests that the treatment of human and animal excreta continues to be inadequate.

Key words Soil microbiology; parasites; helminths; indigenous population; intestinal diseases, parasitic; basic sanitation; Brazil.

Enteroparasitoses and fecal contamination are important public health and environmental problems in developing countries. From an eco-epidemiological

1 Department of Health Sciences, Maringá State University, Maringá, Paraná, Brazil. Send correspondence to: Max Jean O Toledo, Departamento de Ciências Básicas da Saúde, Universidade Estadual de Maringá, Avenida Colombo 5790, Bloco I-90, 87020-900 Maringá, Paraná, Brazil; e-mail: mjotoledo@uem.br

2 Department of History, Maringá State University, Maringá, Paraná, Brazil. perspective, contamination of soil and water, defecation practices, hygiene standards, and water supply standards are the most influential factors on the prevalence of these parasitoses (1).

Enteroparasitism is an important component of the epidemiological profile of the indigenous peoples of Brazil. Although limited to a few ethnic groups, studies on this theme tend to indicate moderate and high prevalences, reflecting the lack of infrastructure for collect- ing wastes and the lack of potable water, in addition to inadequate hygiene habits of the population (2).

In an attempt to improve human health in the indigenous territories (ITs) of Brazil, since 1999 the Ministry of Health, through the National Health Foundation (Fundação Nacional de Saúde, FUNASA), has been implementing various sanitation measures, including residential sanitary improvements and the installation of water lines and water 
treatment systems, and providing training for indigenous health agents (3). Despite these measures, the rates of enteroparasites continue to be high. According to three coproparasitological surveys carried out from 2004 to 2006 among Kaingáng people living in the Faxinal and Ivaí ITs in the State of Paraná, total prevalence of enteroparasites was between $86.9 \%$ and $94.7 \%$ in both ITs, but the intensity of soil-transmitted helminth infections was low $(4,5)$. Data from these studies showed that this high rate of parasitic infections persists despite the implementation of the sanitation measures described above.

The principal objective of implementing sanitation measures within a community is to reduce the degree of contamination of soil and water by pathogens (6). Measurement of the degree of soil contamination by infective parasitic forms (PFs) allows for evaluation of the local population's risk of contracting parasites. Because the people of the Faxinal and Ivaí ITs have inadequate hygiene habits, peri-household areas and public spaces such as school courtyards often become contaminated by the etiological agents of parasitoses and zoonoses-an important source of human-parasitic infection. To help build the data required to assess the effect of sanitation measures in Paraná's ITs, the objectives of the current study were to determine 1 ) the degree of soil contamination by parasites; 2 ) the prevalence of contaminated samples; 3) the overall number of parasitic forms by distance between the collection site and the domicile; 4) the mean number of parasite forms per peri-household area; and 5) the variables associated with the total number of parasite forms.

\section{MATERIALS AND METHODS}

From March 2005 through October 2006, a cross-sectional survey was carried out in the Faxinal and Ivaí ITs, which are located in the central part of the State of Paraná in southern Brazil and inhabited by members of the Kaingáng ethnic group. The Faxinal IT is in the municipality of Cândido de Abreu (51 $\left.{ }^{\circ} 17^{\prime} \mathrm{W} 24^{\circ} 41^{\prime} \mathrm{S}\right), 6 \mathrm{~km}$ from the nearest urban area. An estimated 447 people live in the Faxinal IT, which has a total area of 2044 ha (7). The Ivaí IT is $40 \mathrm{~km}$ from Faxinal and is located in the municipalities of Manoel Ribas and Pitanga (51ํำ $\left.\mathrm{W} 24^{\circ} 42^{\prime} \mathrm{S}\right), 3 \mathrm{~km}$ from the nearest urban area. With a total area of 7200 ha, a population of about 1300 people, and a high population growth rate, the Ivaí IT is one of the largest of the 20 ITs in Paraná State (8).

The regional climate in Faxinal and Ivaí consists of hot summers, without a distinct dry season. Mean summer temperatures are about $20^{\circ} \mathrm{C}$ to $22{ }^{\circ} \mathrm{C}$, and mean temperatures in the coldest month of the year are less than $18{ }^{\circ} \mathrm{C}$. The maximum temperature is $38^{\circ} \mathrm{C}$ whereas the absolute minimum is $-2{ }^{\circ} \mathrm{C}$, and there are 12 to 15 days of frost per year. Relative humidity varies between $75 \%$ and $95 \%$, depending on the dominant air mass. The altitude ranges from $800 \mathrm{~m}$ to $1000 \mathrm{~m}$; this uneven relief has a strong influence on the microclimates. Both ITs lie within the Mixed Ombrophile Forest-also known as the Araucaria Forest biomes, and by various local names, including floresta de pinheiros, pinhais, and pinheirais (all meaning "pine forest" $^{\prime \prime}$. The region includes different types of natural vegetation (ranging from areas that have been used for short or long periods to areas with forests in the initial, intermediate, or advanced successional stages), with approximate heights varying from $10 \mathrm{~m}$ to $30 \mathrm{~m}$ and individual trees with trunk diameters between $5 \mathrm{~cm}$ and $150 \mathrm{~cm}$. In Ivaí, the soil is clayey, whereas sandy soil predominates in Faxinal. In the mountainous part of the region, rainfall can reach $2000 \mathrm{~mm}$ (over a period of 120 days). To the east, rainfall decreases by half (over 90 to 100 days of rain). To the west, rainfall increases, reaching $1500 \mathrm{~mm}$ (over 110 days). Most rainfall occurs from November through January $(7,8)$.

Until the 1940s, the Kaingáng people who occupied the valley of the Ivaí River were composed of various groups that lived in settlements along the river and its tributaries. They subsisted by cultivating corn, beans, squash, and manioc; hunting small mammals and birds; fishing; and collecting various fruits and plants. Essentially, they managed the natural resources of large territories in the upper and middle basin of the Ivaí River. Following the drastic reduction of their territories during the 1950s, they began to concentrate their dwellings in the village headquarters. This shift in housing patterns increased Kaingáng population density and led to a more sedentary lifestyle. They now inhabit a territory with defined boundaries, where the majority of the population lives to- gether in villages composed of closely clustered houses. The current population of Kaingáng in both Faxinal and Ivaí tends to be concentrated in their respective village headquarters. Although the IT in Ivaí is larger in area than the one in Faxinal, its more numerous population is concentrated in only one village and thus has a higher density than that of the Faxinal IT (9).

The Kaingáng population subsists by farming small family plots and collective plots administered by local community leaders and FUNAI (Fundação Nacional do Indio), and from the sale of handicrafts, income from the pensions and salaries of some of its members, and assistance from various social programs of the state and federal government. Because both the Faxinal and Ivaí ITs are relatively close to urban centers $(6 \mathrm{~km}$ and $3 \mathrm{~km}$ respectively), their traditional culture has been somewhat altered. For example, most Kaingáng consume industrialized products acquired in the supermarkets of the cities of Manoel Ribas and Cândido de Abreu (9).

Both ITs have piped water and water treatment systems. At the end of the 1990s, some sanitation facilities were constructed in Ivaí. Residential sanitation improvements initiated in 2003 in Faxinal and in 2004 in Ivaí are being implemented through a partnership between state and federal government. Other interventions have also been carried out, including treatment of the human population with anthelmintics, albeit in a non-systematic way. A mass treatment with albendazole was carried out in 2005 by the staff of the local basic health unit (primary care center).

Eighteen of a total of 63 domiciles in Faxinal and 22 of 190 in Ivaí were randomly selected for study. All houses in the two village headquarters were mapped and numbered, and residences where peri-household soil was to be analyzed were selected by lot. Soil samples were also taken from the courtyards of the local indigenous schools. To facilitate the presentation and discussion of the study results, school courtyards and areas around the surveyed households are referred to as the "peridomicile."

The statistical package Epi Info ${ }^{\mathrm{TM}}$, version 3.5.1 (Centers for Disease Control and Prevention, Atlanta, Georgia, USA), was used to calculate all statistics, including the population of each village and an expected frequency of $94.6 \%$, 
which was the prevalence of enteroparasites in this population in 2005 (5). A total of 111 soil samples from Faxinal and 132 from Ivaí were examined, thus obtaining a confidence level above $95 \%$ for both villages. Six soil samples were collected from different points in the peridomicile of each residence. Two samples were collected at points located up to $1 \mathrm{~m}$ from the house, two between $1 \mathrm{~m}$ and $5 \mathrm{~m}$, and another two located more than $5 \mathrm{~m}$ from the residence. The collections were made from March 2005 through October 2006 in order to obtain a large number of samples from all four seasons of the year. The soil was removed to a depth of $5 \mathrm{~cm}$ in an area of $0.16 \mathrm{~m}^{2}$. The $200-\mathrm{g}$ samples were placed in plastic bags, labeled, and processed immediately upon arrival at the Parasitology Laboratory (Laboratório de Parasitologia) of Maringá State University.

With the help of an indigenous health agent from the local community, soil samples were collected and a questionnaire was given to the head of the family of each residence to determine the factors related to the living and hygiene conditions that might influence soil contamination. The association between number of PFs found in the soil of each domicile and four variables (presence of a bathroom in the domicile, use of the bathroom by the residents of the domicile, presence of domestic animals, and presence of human and animal feces on the peridomiciliar soil) was assessed.

In the parasitological analysis of the soil, three techniques were used for each sample: 1) the Baermann method, as modified by Tiyo et al. (10), for extraction and diagnosis of larval helminths in the soil, using a 30-g aliquot of the sample; 2) the modified method of Faust et al. (11), to assess the presence of cysts of protozoa and light helminth eggs, using a 20-g aliquot of soil in zinc sulphate (density 1:420), and analyzing $0.3 \mathrm{~mL}$ of the material; and 3) the Lutz method (12) for water sedimentation, to assess the presence of helminth eggs, using a 50-g aliquot of soil and analyzing $0.5 \mathrm{~mL}$ of the sediment.

The results of the laboratory analysis were expressed quantitatively as the number of eggs, larvae, cysts, or oocysts found in each sample. Parasites considered to be of veterinary importance only were not included in the analysis or discussion because they do not pose health risks to the human population.
The data were tabulated and later processed and analyzed through statistical programs. Variable prevalence (by IT) and overall number of PFs (by distance from the house) were determined through univariate analysis, using either the chi-square test $\left(\chi^{2}\right)$ or Fisher's exact test (BioEstat 3.0) for qualitative variables, and the Student's $t$-test for quantitative variables (Statistica 8.0) $(13,14)$. Next, using the data obtained, the Poisson multivariate regression test was carried out to identify any variables associated with the mean number of PFs found in the soil (by IT). To assess the association of the seasonality variable with $\mathrm{PF}$ prevalence, the results of soil samples collected during the summer, fall, and winter were compared with those from the spring, since the degree of soil contamination can be influenced by regional climatic conditions. The results obtained from 1) households reporting the presence of a bathroom and 2) those reporting use of the bathroom were compared with the results from both households without a bathroom and those that did not report use of one, respectively. In addition, the number of PFs was compared between households with and without domestic animals, and between those with and without feces on the peridomiciliar soil (15).

The project was approved by the National Research Ethics Committee (Comitê Nacional de Ética em Pesquisa, CONEP), in conformity with its report no. 815/2004. Signed statements approving the study were obtained from local leaders as well as the boards of health of the Special Indigenous Health District (Distrito Sanitário Especial Indigena, DSEI) of the Faxinal and Ivaí ITs. At the end of each survey, the results were presented to local authorities, community leaders, and the study subjects.

\section{RESULTS}

\section{Prevalence of contaminated samples}

Of the 111 samples obtained from the Faxinal IT and the 132 samples from the Ivaí IT, 75.7\% (95\% confidence interval $[95 \% \mathrm{CI}]=67.7-83.7)$ and $96.2 \%(95 \%$ $\mathrm{CI}=92.9-99.5)$ respectively were contaminated with parasites from either humans or animals with zoonotic potential. The frequency of contaminated samples was higher in Ivaí, but this difference was not significant (Table 1). At least one soil sample from each peridomicile analyzed contained a parasite.

Because it was difficult to identify morphologically the species of the PFs (eggs, larvae, cysts, and oocysts) found in the soil, most classification was limited to genus (with some species classified to family or superfamily). Of the 20 different protozoa and helminths found in the soil, 14 were enteroparasites of either humans or animals with zoonotic potential; the remaining six were either parasites of veterinary importance only, or commensals (Table 1). The PFs found most often in soil samples from Faxinal and Ivaí were: eggs of Ascaris spp. (52.3\% and $67.4 \%$, respectively), Toxocara spp. $(28.8 \%$ and $42.4 \%)$, and Trichuris spp. (5.4\% and $11.4 \%)$; oocysts of Isospora spp. $(44.1 \%$ and $73.5 \%)$; and cysts of Entamoeba spp. (22.5\% and $49.2 \%)$ and Endolimax nana $(9.0 \%$ and $21.2 \%)$. The prevalence of three forms (Isospora spp., Entamoeba spp., and E. nana) differed significantly between the two ITs $(P=0.019$, 0.032 , and 0.025 , respectively) (Table 1 ).

\section{Overall number of parasitic forms by distance between collection site and domicile}

Of the six PFs found most often in the soil of the Faxinal IT, only the number of eggs of Trichuris spp. did not vary significantly with respect to the distance between the collection site and the domicile (Table 2). Oocysts of Isospora spp. were the PFs found most often in this IT and occurred significantly more often between $1 \mathrm{~m}$ and $5 \mathrm{~m}$ from the domicile $(P=0.000)$, as did the eggs of Toxocara spp. Cysts of Entamoeba spp. were most often found up to $1 \mathrm{~m}$ from the domicile, whereas eggs of Ascaris spp. were most prevalent both up to $1 \mathrm{~m}$ and more than $5 \mathrm{~m}$ from the domicile, and cysts of Giardia spp. were most often found more than $5 \mathrm{~m}$ from the residence (Table 2).

In the Ivaí IT, among the six parasites found most often, Ascaris spp. eggs were most prevalent, and the number of eggs found increased significantly $(P=0.000)$ with distance from the house (Table 2). Oocysts of Isospora spp. and eggs of Trichuris spp. were detected significantly more often in soil collected between $1 \mathrm{~m}$ and $5 \mathrm{~m}$ from the domicile, whereas cysts of Entamoeba spp. were most prevalent up to $1 \mathrm{~m}$ from the domicile, as in the Faxinal IT. The number of both the eggs of Toxocara spp. and the cysts of $\mathrm{Gi}$ - 
TABLE 1. Overall prevalence (\%) of parasitic forms (cysts, oocysts, eggs, and larvae) contaminating peridomiciliar soil samples, by major taxon (species, genus, family, and superfamily), Faxinal and Ivaí indigenous territories, Paraná, Brazil, March 2005-October 2006

\begin{tabular}{|c|c|c|c|c|c|}
\hline & \multirow[b]{2}{*}{ Parasite } & \multicolumn{2}{|c|}{ Prevalence (\%) of parasitic forms } & \multirow[b]{2}{*}{$\chi^{2 b}$} & \multirow[b]{2}{*}{$P$} \\
\hline & & $\begin{array}{c}\text { Faxinal } \\
\left(n^{\mathrm{a}}=111\right)\end{array}$ & $\begin{array}{c}\text { Ivaí } \\
(n=132)\end{array}$ & & \\
\hline \multirow[t]{9}{*}{ Protozoa } & Isospora spp. (oocyst) & 44.1 & 73.5 & 5.53 & 0.019 \\
\hline & Entamoeba spp. (cyst) & 22.5 & 49.2 & 8.71 & 0.032 \\
\hline & Endolimax nana (cyst) & 9.0 & 21.2 & 5.03 & 0.025 \\
\hline & Giardia spp. (cyst) & 6.3 & 1.5 & 3.59 & $N S^{c}$ \\
\hline & Eimeria spp. (oocyst) & 4.5 & 3.0 & 0.06 & NS \\
\hline & Other coccidian oocyst & 0.0 & 2.3 & $N A^{d}$ & NA \\
\hline & Chilomastix spp. (cyst) & 0.9 & 0.0 & NA & NA \\
\hline & Sarcocystis spp. (cyst) & 0.0 & 0.8 & NA & NA \\
\hline & Blastocystis spp. (cyst) & 0.0 & 0.8 & NA & NA \\
\hline \multirow{11}{*}{ Helminths } & Ascaris spp. (egg) & 52.3 & 67.4 & 0.34 & NS \\
\hline & Toxocara spp. (egg) & 28.8 & 42.4 & 2.28 & NS \\
\hline & Trichuris spp. (egg) & 5.4 & 11.4 & 2.29 & NS \\
\hline & Ancylostomatoidea (egg) & 9.0 & 6.8 & 0.34 & NS \\
\hline & Trichostrongyloidea (egg) & 1.8 & 5.3 & 1.10 & NS \\
\hline & Ancylostomatoidea (larva) & 0.0 & 0.3 & NA & NA \\
\hline & Taenia spp. (egg) & 2.7 & 1.5 & 0.03 & NS \\
\hline & Strongyloides spp. (larva) & 0.9 & 1.5 & 0.02 & NS \\
\hline & Hymenolepis nana (egg) & 0.9 & 0.0 & NA & NA \\
\hline & Toxascaris spp. (egg) & 0.9 & 0.8 & NA & NA \\
\hline & Oxyuroidea (egg) & 0.0 & 0.8 & NA & NA \\
\hline \multicolumn{2}{|c|}{ Overall prevalence } & 75.7 & 96.2 & 1.59 & NS \\
\hline
\end{tabular}

TABLE 2. Overall number of parasitic forms (cysts, oocysts, eggs, and larvae), by distance between collection site and domicile, Faxinal and Ivaí indigenous territories, Paraná, Brazil, March 2005-October 2006

\begin{tabular}{|c|c|c|c|c|c|c|c|c|c|c|c|c|}
\hline \multirow[b]{3}{*}{ Parasite } & \multicolumn{8}{|c|}{$\begin{array}{l}\text { Distance between collection site and domicile in Faxinal and Ivaí, } \\
\text { and number of parasitic forms }\end{array}$} & & & & \\
\hline & \multicolumn{2}{|c|}{$<1 \mathrm{~m}$} & \multicolumn{2}{|c|}{$1-5 m$} & \multicolumn{2}{|c|}{$>5 \mathrm{~m}$} & \multicolumn{2}{|c|}{ Total } & \multicolumn{2}{|c|}{$\chi^{2 b}$} & \multicolumn{2}{|c|}{$P$} \\
\hline & $\begin{array}{l}\text { Faxinal } \\
\left(n^{a}=36\right)\end{array}$ & $\begin{array}{c}\text { Ivaí } \\
(n=44)\end{array}$ & $\begin{array}{l}\text { Faxinal } \\
(n=36)\end{array}$ & $\begin{array}{c}\text { Ivaí } \\
(n=44)\end{array}$ & $\begin{array}{l}\text { Faxinal } \\
(n=39)\end{array}$ & $\begin{array}{c}\text { Ivaí } \\
(n=44)\end{array}$ & $\begin{array}{l}\text { Faxinal } \\
(n=111)\end{array}$ & $\begin{array}{c}\text { Ivaí } \\
(n=132)\end{array}$ & Faxinal & Ivaí & Faxinal & Ivaí \\
\hline Isospora spp. (oocyst) & 408 & 225 & 1410 & 266 & 222 & 251 & 2040 & 742 & 395.9 & 7.18 & 0.000 & 0.028 \\
\hline Entamoeba spp. (cyst) & 114 & 163 & 54 & 107 & 92 & 127 & 260 & 397 & 653.0 & 48.9 & 0.000 & 0.000 \\
\hline Ascaris spp. (egg) & 86 & 314 & 38 & 586 & 87 & 615 & 211 & 1515 & 176.9 & 58.8 & 0.000 & 0.000 \\
\hline Toxocara spp. (egg) & 9 & 68 & 58 & 66 & 30 & 86 & 97 & 220 & 19.0 & 4.45 & $<0.001$ & $\mathrm{NS}^{\mathrm{c}}$ \\
\hline Giardia spp. (cyst) & 2 & 2 & 4 & 2 & 22 & 0 & 28 & 4 & 73.4 & 2.5 & 0.000 & NS \\
\hline Trichuris spp. (egg) & 2 & 11 & 2 & 26 & 4 & 10 & 8 & 47 & 6.46 & 8.1 & NS & 0.018 \\
\hline Total & 621 & 783 & 1566 & 1053 & 457 & 1089 & 2644 & 2925 & & & & \\
\hline
\end{tabular}

a $n=$ number of soil samples tested.

b Pearson's chi-square test statistic.

${ }^{\mathrm{c}} \mathrm{NS}=$ not significant

ardia spp. did not vary by distance from the house (Table 2).

\section{Mean number of parasite forms per peridomicile}

Because the same amount of soil was analyzed from each sample, it was possible to obtain the mean number of PFs found in the peridomiciles of the two village headquarters and to assess whether they differed in degree of contamination for each species. The mean total number of PFs per peridomicile was higher in the Faxinal IT (148.6) versus the Ivaí IT (134.6), although this difference was not significant (Table 3). The majority of the PFs collected from Ivaí, especially the eggs of Ascaris spp., showed higher mean prevalences, with a significantly $(P=0.002)$ greater contamination of the soil in this IT by this helminth.

\section{Variables associated with total number of parasite forms}

Comparison of the results obtained in the two ITs showed that the overall mean number of PFs in peridomiciliar soil did not vary significantly (Table 3 ). Analysis by season showed a significant decrease $(0.26, P<0.001)$ in the mean number of PFs in the soil during summer, and a significant increase in the fall 
TABLE 3. Mean number per major taxon (species, genus, family, and superfamily) and total mean of parasitic forms (cysts, oocysts, eggs, and larvae) collected in peridomiciliar soil, Faxinal and Ivaí indigenous territories, Paraná, Brazil, March 2005-October 2006

\begin{tabular}{|c|c|c|c|c|c|c|}
\hline \multirow[b]{3}{*}{ Parasite } & \multicolumn{4}{|c|}{ Mean and $\mathrm{SD}^{\mathrm{a}}$ of parasitic forms } & \multirow[b]{3}{*}{$t^{\mathrm{b}}$} & \multirow[b]{3}{*}{$P$} \\
\hline & \multicolumn{2}{|c|}{$\begin{array}{l}\text { Faxinal } \\
(n=18)\end{array}$} & \multicolumn{2}{|c|}{$\begin{array}{c}\text { Ivaí } \\
(n=22)\end{array}$} & & \\
\hline & Mean & SD & Mean & SD & & \\
\hline Isospora spp. (oocyst) & 113.3 & 279.59 & 33.8 & 26.01 & 1.33 & $\mathrm{NS}^{\mathrm{c}}$ \\
\hline Ascaris spp. (egg) & 11.7 & 9.96 & 68.9 & 72.15 & -3.33 & 0.002 \\
\hline Entamoeba spp. (cyst) & 14.4 & 26.90 & 18.0 & 15.19 & -0.53 & NS \\
\hline Toxocara spp. (egg) & 5.4 & 6.91 & 10.0 & 8.18 & -1.90 & NS \\
\hline Trichuris spp. (egg) & 0.4 & 0.70 & 2.1 & 5.12 & -1.39 & NS \\
\hline Giardia spp. (cyst) & 1.6 & 5.41 & 0.2 & 0.85 & 1.18 & NS \\
\hline Ancylostomatoidea (egg) & 1.4 & 3.28 & 0.7 & 1.09 & 1.03 & NS \\
\hline Taenia spp. (egg) & 0.2 & 0.38 & 0.6 & 2.06 & -0.86 & NS \\
\hline Ancylostomatoidea (larva) & 0.0 & 0.00 & 0.2 & 0.39 & $N A^{d}$ & NA \\
\hline Strongyloides spp. (larva) & 0.1 & 0.24 & 0.1 & 0.43 & -0.31 & NS \\
\hline Hymenolepis nana (egg) & 0.1 & 0.24 & 0.0 & 0.00 & NA & NA \\
\hline Sarcocystis spp. (cyst) & 0.0 & 0.00 & 0.1 & 0.21 & NA & NA \\
\hline Blastocystis spp. (cyst) & 0.0 & 0.00 & 0.1 & 0.43 & NA & NA \\
\hline Total mean & 148.6 & 289.29 & 134.6 & 85.89 & 0.22 & NS \\
\hline
\end{tabular}

TABLE 4. Variables associated with total number of parasitic forms (cysts, oocysts, eggs, and larvae) found in peridomiciliar soil, according to the Poisson statistical model, Faxinal and Ivaí indigenous territories, Paraná, Brazil, March 2005-0ctober 2006

\begin{tabular}{|c|c|c|c|c|c|c|c|}
\hline \multirow[b]{4}{*}{ Variable } & & \multicolumn{6}{|c|}{ Statistical analysis } \\
\hline & & & & \multicolumn{4}{|c|}{ Poisson multivariate regression } \\
\hline & & \multicolumn{2}{|c|}{ Frequency } & \multirow[b]{2}{*}{ Estimate } & \multirow{2}{*}{$\begin{array}{c}\text { Standard } \\
\text { error }\end{array}$} & \multirow[b]{2}{*}{$95 \% \mathrm{Cl}^{\mathrm{a}}$} & \multirow[b]{2}{*}{$P$} \\
\hline & & No. & $\%$ & & & & \\
\hline Domiciles per locality & $\begin{array}{l}\text { Faxinal } \\
\text { Ivaí }\end{array}$ & $\begin{array}{l}18 \\
22\end{array}$ & $\begin{array}{l}45 \\
55\end{array}$ & 0.01 & 0.02 & -0.03 to 0.05 & 0.642 \\
\hline Season & $\begin{array}{l}\text { Spring } \\
\text { Summer } \\
\text { Fall } \\
\text { Winter }\end{array}$ & $\begin{array}{r}6 \\
12 \\
10 \\
12\end{array}$ & $\begin{array}{l}15 \\
30 \\
25 \\
30\end{array}$ & $\begin{array}{r}-0.26 \\
0.08 \\
0.72\end{array}$ & $\begin{array}{l}0.03 \\
0.03 \\
0.03\end{array}$ & $\begin{array}{c}-0.32 \text { to }-0.20 \\
0.02 \text { to } 0.14 \\
0.66 \text { to } 0.78\end{array}$ & $\begin{array}{r}<0.001 \\
0.005 \\
<0.001\end{array}$ \\
\hline Presence of bathroom in domicile & $\begin{array}{l}\text { Yes } \\
\text { No }\end{array}$ & $\begin{array}{l}30 \\
10\end{array}$ & $\begin{array}{l}75 \\
25\end{array}$ & 0.44 & 0.03 & 0.38 to 0.50 & $<0.001$ \\
\hline Use of bathroom by domicile residents & $\begin{array}{l}\text { Yes } \\
\text { No }\end{array}$ & $\begin{array}{r}32 \\
8\end{array}$ & $\begin{array}{l}80 \\
20\end{array}$ & -0.02 & 0.03 & -0.08 to 0.04 & 0.418 \\
\hline Presence of domestic animals & $\begin{array}{l}\text { Yes } \\
\text { No }\end{array}$ & $\begin{array}{l}27 \\
13\end{array}$ & $\begin{array}{l}67.5 \\
32.5\end{array}$ & 0.01 & 0.02 & -0.03 to 0.05 & 0.576 \\
\hline Feces on the soil & $\begin{array}{l}\text { Yes } \\
\text { No }\end{array}$ & $\begin{array}{r}31 \\
9\end{array}$ & $\begin{array}{l}77.5 \\
22.5\end{array}$ & 0.25 & 0.03 & 0.19 to 0.31 & $<0.001$ \\
\hline
\end{tabular}

and winter $(0.08, P=0.005$, and $0.72, P<$ 0.001 , respectively), compared to spring (Table 4).

Of the 40 domiciliary units investigated, $75.0 \%$ possessed a bathroom. Presence of a bathroom significantly increased $(0.44, P<0.001)$ the mean number of PFs in the soil versus domiciles that did not have a bathroom (Table 4). Use of the bathroom, reported by resi- dents of $80.0 \%$ of the domiciles, decreased the mean number of PFs in the soil versus the $20.0 \%$ of residents who did not use a bathroom, but this change (0.02) was not significant. The data also showed that the number of PFs in the soil did not change with the presence of domestic animals (reported by $67.5 \%$ of the families). However, the presence of feces, observed on the ground at $77.5 \%$ of the peridomiciles, increased the number of PFs in the soil $(P<0.001)$ by 0.25 versus households without visible feces on their peridomiciliar soil (Table 4).

\section{DISCUSSION}

Brazilian indigenous communities are widely affected by enteroparasitoses due to inadequate sanitation infrastructure, a 
deficit that exposes the population to infections and reinfections (16-19). Despite this situation, few environmental studies have been conducted to determine the level of IT soil contamination by human enteroparasites or by animal enteroparasites with zoonotic potential. The current study revealed high levels of contamination of soil by parasites in both ITs: $75.7 \%$ of the samples from Faxinal and $96.2 \%$ of those from Ivaí. Navone et al. (1), analyzing 67 samples of soil from villages of the Mbyá-Guarani people in Misiones Province, Argentina, found that $41.8 \%$ of them were contaminated by enteroparasites, a lower prevalence than that observed in the present study. In addition to poor hygiene habits, the sedentary lifestyle and higher population density of the Kaingáng living in the ITs may contribute to the high number of contaminated soil samples.

In a study of soils in a rural environment in Vietnam, high indices of parasitoses and poor sanitation conditions were also observed (20). The authors of the study found a prevalence of $100.0 \%$ and $87.5 \%$ for eggs of Ascaris lumbricoides and Trichuris trichiura, respectively. These prevalences were higher than those observed in the soil of the two Kaingáng villages in Paraná due to the Vietnamese villagers' use of human feces as fertilizer.

In contrast to the scarce data in the literature on parasitological analysis of soils of rural environments and closed communities such as the ITs, there is a considerable amount of information on parasite contamination of the soils of urban environments such as parks, beaches, and public plazas used for leisure and recreation in Brazil $(10,21-23)$ and in other countries (24).

In soils from public recreation areas, the most prevalent parasites are Toxocara spp., exclusively of animals, and Ancylostoma sp. However, some studies have also revealed the presence of oocysts of Isospora spp. and of eggs of ancylostomids, Ascaris spp., and Trichuris spp., which can have human as well as animal hosts $(22,23,25)$. The prevalence of enteroparasites in urban areas was lower than that found in the soil of the ITs. This was attributed to the presence of fecal matter generated by the large numbers of domestic animals in the ITs (dogs, pigs, chickens, cats, horses, ducks, etc.), and humans. Human waste is common due to the fact that some members of the human population still defecate on the ground. This finding was based on observation of human feces in the peridomicile, and of individuals, especially children, carrying out this practice.

In soil parasite analysis, it is not uncommon to find PFs from host species other than humans. However, in most cases, it is not possible to identify the specific sources of the PFs. Moreover, the loss of important structures in the samples and the morphological similarities between the evolutionary stages of different species impedes their classification to species level (26). Examples include the eggs of $A$. lumbricoides and Ascaris suum (which, though morphologically identical, parasitize different hosts-humans and swine, respectively (27)) and the eggs of Toxocara canis and Toxocara cati of dogs and cats (24).

Because some animal parasites can also infect humans, these species should be considered in soil contamination studies. In the current study, large numbers of free-roaming domestic animals, including pigs, were observed. While there is still some controversy about whether A. suum (large roundworm of pigs) can infect humans, human-parasitic forms of this helminth appear to be location specific. For example, data from Guatemala suggest there is no intraspecific transmission between pigs and humans (28) and that programs aiming to control $A s-$ caris infection in the human population can safely ignore zoonotic infection from pigs (29), whereas the Nejsum et al. study (27) of the association between Ascaris infections in Danish patients and swine or swine manure, using molecular biology techniques, proved that patients had acquired Ascaris from domestic swine and that ascaridiasis is a zoonotic disease. Results such as those from the Danish study, along with the high prevalence of Ascaris found in this study $(>50 \%)$, which is not uncommon, indicate the need to assess contamination from animal as well as human parasites in studies investigating the potential effects on human health.

The level of contamination of the soils of Faxinal and Ivaí was associated with the rate of parasitic infection, based on data obtained from fecal examinations of household residents $(4,5)$. All genera of human intestinal protozoa and helminths found in the coproparasitological study, other than Enterobius vermicularis, were also found in the soil. This further proves that the local population (at least part of it) continues to defecate on the ground, supporting the hypothesis that some of the PFs found in the study came from human hosts.

Factors that influence the probability that infective forms of a parasite will find susceptible hosts in indigenous communities include the degree of cultural change; type of residence (e.g., earthen versus concrete/masonry floor), lifestyle (sedentary versus nomadic); and population density. In indigenous communities of the Peruvian Amazon, Kroeger et al. (30) observed that the intensity of infection by intestinal helminths was significantly lower in less-acculturated communities. In the Venezuelan Amazon, in their research among the Piaroa indigenous people, which analyzed the effect of community size on number of cases testing positive for geohelminths, as well as parasite load, using regression analysis, Gómez et al. (31) observed that the number of cases testing positive for A. lumbricoides, $T$. trichiura, and ancylostomids significantly increased according to the size of the community (i.e., the larger the community evaluated, the larger the parasite load and the number of persons infected, indicating that a higher population density favors the transmission of these parasites). The investigators for that study found a higher frequency (albeit a low level of infection) of individuals parasitized by ancylostomids associated with a type of indigenous dwelling in which the principal residence has mud walls, a straw roof, and an earthen floor.

The common epidemiological pattern among isolated indigenous peoples in Amazonia indicates a high prevalencelow intensity pattern of infection (30). Data obtained by the authors of this study in coproparasitological research carried out with the populations of the Faxinal and Ivaí ITs from 2004 through 2006 showed a high prevalence of enteroparasites for both groups but a variance in the intensity of soil-transmitted helminth infections, with the Faxinal IT showing a pattern of low intensity and the Ivaí IT a high one $(4,5,32)$. Because lifestyle, type of residence, and degree of cultural change are similar for both ITs, it seems likely that the higher population density and parasite load among the Ivaí population $(4,32)$ may have influenced the prevalence of Isospora spp., Endolimax spp., and Entamoeba spp. as well as the mean number of eggs of Ascaris spp. in 
the soil, which were significantly higher in this IT.

It is important to consider seasonality in soil contamination studies because the occurrence of enteroparasites is affected by environmental factors such as temperature, humidity, and soil type (26). The survival of parasites' eggs depends on certain seasonal conditions that help them 1) resist constraints in their external environment, 2) continue their life cycle, and 3) produce infective forms and thus reach a new host. The Poisson statistical model showed that the number of total PFs was significantly influenced by seasonality, declining in summer and increasing in fall and winter. A similar situation was observed by Tiyo et al. (10), who found more PFs in the soil of urban areas in winter versus spring, fall, and summer. In the current study, high prevalence of contaminated samples was seen throughout all four seasons for the majority of taxa found, with the exception of the larvae of Ancylostomatoidea, which were detected only in the summer, probably due to the higher level of moisture in the soil during this season. Another important finding was the high level of embryonated helminth eggs, with moving larvae in their interiors, during the summer season, suggesting that in addition to helping to destroy the more sensitive PFs, high summer temperatures may induce embryonation of the more resistant eggs, such as those of Ascaris spp., Toxocara spp., and Trichuris spp., which require high temperature and humidity to become infective (26).

One of the variables associated with soil contamination was the presence of bathrooms, which were observed in 3/4 of the domiciles and, according to the self-reported survey data, used by $80.0 \%$ of the residents. Surprisingly, the presence of a bathroom in a residence did not decrease the level of contamination in the household soil sample. On the contrary, the presence of a bathroom was significantly related to a larger number of PFs in the peridomiciliar soil. This finding suggests that although the majority of household residents surveyed stated that they used a bathroom, if one was available, in practice they do not, either because they do not know how or because their respective bathrooms are broken. Another survey carried out by the authors of the current study found that $26 \%$ and $56 \%$ of the bathrooms in the Faxinal and Ivaí IT respectively were not functioning (32). In most cases, the malfunction was due to clogged or broken pipes, or lack of water supply, highlighting the insufficient maintenance of sanitation facilities. In a study published in 1992, Schulz and Kroeger (33) observed that not only was there no significant correlation between decreased soil contamination levels and the presence or quality of latrines or flush toilets but houses with flush toilets were often the source of fecal contamination of the neighborhood, due to the absence of an adequate sewage system. In their study of the Piaroa indigenous community, Gómez et al. (31) obtained similar results, observing that individuals who lived in Western-style houses (dwellings with masonry walls, galvanized-iron roofs, and concrete floors) had higher parasite loads than those who lived in indigenous-type dwellings. These outcomes demonstrate that developing, applying, and providing access to new technologies may not improve human health if the target population does not know how to use them correctly (31). Without the proper training and maintenance, such innovations may even prove unfavorable to the local population by altering the transmission of parasitic infections.

The data obtained in the current study showed that 1) a majority of the parasitic structures found in the soil samples did not belong to human-parasitic species, 2) soil contamination significantly increased with the presence of feces in the peridomicile, and 3) the degree of contamination in the peridomicile was not influenced by the presence of domestic animals (which were free-roaming and could therefore defecate outside the perihousehold area).

\section{Limitations}

It should be noted that while the current study's analysis of soil samples allowed for verification of the presence of several species of parasites, it did not elucidate the impact of sanitation measures implemented prior to the study, due to the lack of pre-implementation data on the level of soil contamination. For the same reason, an evaluation conducted six years after the implementation of sanitation measures did not indi- cate if any changes had occurred as a result of those measures (although it did provide some useful information). Nevertheless, it seems likely that the sanitation campaign has reduced the numbers of parasitic forms that existed before sanitation measures were initiated in 1998.

The study data showed that the contamination of peridomiciliar soil can vary significantly according to the distance between the domicile and the collection site, depending on the parasite species and the locality. Of the total number of oocysts of Isospora spp. recorded for the peridomiciles in Faxinal (2 040), 1162 (57\%) were found in a single soil sample collected between $1 \mathrm{~m}$ and $5 \mathrm{~m}$ from the house. In other words, the soil parasites may have aggregated distributions. Similar data were obtained in research published in 1992 (33) in which 87\% of all Ascaris eggs found in the study were collected from $10 \%$ of the soil samples. It should be noted that the sample size used in the 1992 research was much larger than that used in the current study, comprising 15-20 samples from each peridomicile and from defecation sites inside or near the residence, and dust from the kitchen and living room floors of each house. These authors also demonstrated that indoor contamination may be significantly higher than contamination in the peridomicile (33).

The use of this kind of study to evaluate mass treatment programs for intestinal parasites should be tested further, with a focus on the relationship between soil contamination and epidemiological data, particularly the intensity of infection in the human population, as well as environmental and social risk factors. It may be useful to evaluate the effect of the mass albendazole treatment (for humans) carried out in 2005 and the ivermectin treatment (for animals producing Toxocara species) administered in 2008 , although the use of this approach would require a longer monitoring period than that used in the current study.

This study showed that the occurrence of enteroparasitoses among the Kaingáng people of the Faxinal and Ivaí ITs is associated with peridomiciliar contamination, mostly likely due to inadequate maintenance of health facilities, and that part of the population has still not acquired good sanitation habits (i.e., they continue to defecate on the ground and allow their domestic animals to do the 
same, principally in the peridomicile). As a result, peridomiciliar soil in the Faxinal and Ivaí ITs is a significant source of reinfection for children and adults. $\mathrm{AB}$. Parasitosis intestinales en poblaciones Mbyá-Guaraní de la Província de Misiones, Argentina: aspectos epidemiológicos y nutricionales. Cad Saúde Pública. 2006;22(5): 1089-100.

2. Vieira GO. Enteroparasitoses em populações indígenas no Brasil: uma revisão sistemática da produção científica [M.Sc. dissertation]. Rio de Janeiro: Escola Nacional de Saúde Pública, Fundação Oswaldo Cruz; 2003 [cited 10 June 2010]. Available from: http://teses. icict.fiocruz.br/pdf/vieiragom.pdf.

3. Fundação Nacional de Saúde, Ministério da Saúde (BR). Política nacional de atenção a saúde dos povos indígenas. 2nd ed. Brasília (DF): FUNASA, MS; 2002.

4. Paludetto AW. Prevalência e intensidade de infecção por enteroparasitos nos Kaingáng das Terras Indígenas Faxinal e Ivaí, no Estado do Paraná, Sul do Brasil [M.Sc. dissertation]. Maringá (PR): Universidade Estadual de Maringá; 2006.

5. Toledo MJO, Paludetto AW, Moura FT, Nascimento ES, Chaves M, Araújo SM, et al. Evaluation of enteroparasite control activities in a Kaingáng community of Southern Brazil. Rev Saúde Pública. 2009;43(6):981-90.

6. Montresor A, Crompton DWT, Bundy DAP, Hall A, Savioli L. Guidelines for the evaluation of soil-transmitted helminthiasis and schistosomiasis at community level. A guide for managers of control programmes. Geneva: World Health Organization; 1998.

7. Mota LT, Cazorla EM, Rocha FV. Diagnóstico sócio-cultural e econômico da Terra Indígena Faxinal-PR [report from research project]. Maringá (PR): Universidade Estadual de Maringá; 2004.

8. Mota LT. Diagnóstico etno-ambiental da Terra Indígena Ivaí-PR. Maringá (PR): Programa Interdisciplinar de Estudos de Populações; 2003.

9. Mota LT, Novak ES. Os Kaingang do Vale do Rio Ivaí-PR: história e relações interculturais. 1st ed. Maringá (PR): Editora da Universidade Estadual de Maringá; 2008. 190 p.

10. Tiyo R, Guedes TA, Falavigna DL, FalavignaGuilherme AL. Seasonal contamination of public squares and lawns by parasites with zoonotic potential in southern Brazil. J Helminthol. 2008;82(1):1-6.

11. Faust EC, Sawitz W, Tobie J, Odom V, Peres C, Lincicome DR. Comparative efficiency of various techniques for the diagnosis of protozoa and helminth in feces. J Parasitol. 1939;25: 241-61.
Acknowledgments. The authors express their sincere gratitude to the Kaingáng Indians, for their participation in research, and to the National Health

\section{REFERENCES}

12. Lutz A. O Schistosomum mansoni e a schistosomatose segundo observações feitas no Brasil. Mem Inst Oswaldo Cruz. 1919;11:121-55.

13. Vieira S. Introdução à bioestatística. 3rd ed. Rio de Janeiro: Elsevier/Editora Campus; 1998.

14. Soares JF, Siqueira AL. Introdução à estatística médica. Belo Horizonte (MG): Departamento de Estatística, Universidade Federal de Minas Gerais; 1999.

15. Dobson AJ. An introduction to generalized linear models. 2nd ed. New York: Chapman \& Hall/CRC; 2001.

16. Miranda RA, Xavier FB, Menezes RC. Parasitismo intestinal em uma aldeia indígena Parakanã, sudeste do Estado do Pará, Brasil. Cad Saúde Pública. 1998;14(3):507-11.

17. Miranda RA, Xavier FB, Nascimento JRL, Menezes RC. Prevalência de parasitismo intestinal nas aldeias indígenas da tribo Tembé, Amazônia Oriental Brasileira. Rev Soc Bras Med Trop. 1999;32(4):389-93.

18. Scolari C, Torti C, Beltrame A, Matteelli A, Castelli F, Gulletta M, et al. Prevalence and distribution of soil-transmitted helminths (STH) infections in urban and indigenous schoolchildren in Ortigueira, State of Paraná, Brasil: implications for control. Trop Med Int Health. 2000;5(4):302-07.

19. Fontbonne A, Freese-de-Carvalho E, Acioli MD, Sá GA, Cesse EAP. Fatores de risco para poliparasitismo intestinal em uma comunidade indígena de Pernambuco, Brasil. Cad Saúde Pública. 2001;17(2):367-73.

20. Kim HT, De NV, Tien NV, Dang NT, Tuyet PT, Mai NT, et al. Effectiveness of selective treatment in the control of soil-transmitted helminthiases. In: Crompton DWT, Montresor A, Nesheim MC, Savioli L, editors. Controlling disease due to helminth infections. Geneva: World Health Organization; 2003. p. 157-67.

21. Costa-Cruz JM, Nunes RS, Buso AG. Presença de ovos de Toxocara spp. em praças públicas da cidade de Uberlândia, Minas Gerais, Brasil. Rev Inst Med Trop São Paulo. 1994;36:39-42.

22. Santarém VA, Sartor IF, Bergamo FMM. Contaminação por ovos de Toxocara spp. de parques e praças públicas de Botucatu, São Paulo, Brasil. Rev Soc Bras Med Trop. 1998;31: 529-32.

23. Mentz MB, Rott MB, Jacobsen SIV, Baldo G, Rodrigues V Jr. Frequêencia de ovos de Toxocara spp. em três parques públicos da cidade de Porto Alegre, Rio Grande do Sul, Brasil. Rev Patol Trop. 2004;33(1):105-12.

24. Chorazy ML, Richardson DJ. A survey of environmental contamination with ascarid
Foundation (FUNASA), Ministry of Health, for financial support (Procedural no. 3304/04-PPG/UEM no. 0929/04). ova, Wallingford, Connecticut. Vector Borne Zoonotic Dis. 2005;5(1):33-9.

25. Marder G, Ulon SN, Bottinelli OR, Meza Fleitas ZL, Lotero DA, Ruiz RM, et al. Infestación parasitaria de suelos y materia fecal de perros y gatos de la ciudad de Corrientes. Rev Veterinária. 2004;15(2):70-2.

26. Neves DP, Melo AL, Linardi PM, Vitor RWA. Parasitologia humana. 11th ed. São Paulo: Atheneu; 2005.

27. Nejsum P, Parker ED Jr, Frydenberg J, Roepstorff A, Boes J, Haque R, et al. Ascariasis is a zoonosis in Denmark. J Clin Microbiol. 2005;43(3):1142-8.

28. Anderson TJ, Romero-Abal ME, Jaenike J. Genetic structure and epidemiology of Ascaris populations: patterns of host affiliation in Guatemala. Parasitol. 1993;107(Pt 3):319-34.

29. Anderson TJ, Jaenike J. Host specificity, evolutionary relationships and macrogeographic differentiation among Ascaris populations from humans and pigs. Parasitol. 1997;115 (Pt 3):325-42

30. Kroeger A, Schulz S, Witte B, Skewes-Ramm R, Etzler A. Helminthiasis and cultural change in the Peruvian rainforest. J Trop Med Hyg. 1992;95(2):104-13.

31. Gómez J, Botto C, Zent S, Marín A, Sánchez J, Noguera $C$, et al. Influencia del tipo de vivienda y del tamaño de asentamiento de comunidades indígenas Piaroa en la transmisión de helmintos intestinales. Interciencia. 2004; 29(7):389-95.

32. Toledo MJO. Impacto das ações de saneamento na saúde das populações das Terras Indígenas de Ivaí e Faxinal no Estado do Paraná. Relatório final. Maringá (PR): Programa de Pesquisa em Saúde e Saneamento, Departamento de Engenharia de Saúde Pública, Fundação Nacional de Saúde, Ministério da Saúde; 2007.

33. Schulz S, Kroeger A. Soil contamination with Ascaris lumbricoides eggs as an indicator of environmental hygiene in urban areas of northeast Brazil. J Trop Med Hyg. 1992;95(2):95-103.

Manuscript received on 24 November 2009. Revised version accepted for publication on 13 May 2010. 
RESUMEN Objetivos. Determinar: 1) el grado de contaminación parasitaria del suelo; 2) la prevalencia de muestras contaminadas; 3 ) el número general de formas parasitarias, en función de la distancia entre el sitio donde se tomaron las muestras y el domicilio; 4) el número promedio de formas parasitarias por área peridomiciliar y 5) las varia-

Contaminación por enteroparásitos en el suelo peridomiciliar de dos territorios indígenas del estado de Paraná, en el sur del Brasil

Palabras clave bles relacionadas con el número total de formas parasitarias.

Métodos. Se recogieron muestras del suelo de los alrededores de 18 (de una muestra total de 63) y 22 domicilios (de una muestra total de 190) situados en los territorios indígenas Faxinal e Ivaí, respectivamente, entre marzo del 2005 y octubre del 2006. Las muestras se evaluaron mediante los métodos propuestos por Baermann, Faust et al. (modificado) y Lutz.

Resultados. La prevalencia general de las muestras contaminadas por enteroparásitos humanos o animales que se consideraron de potencial zoonótico fue de $75,7 \%$ (84 de 111) en Faxinal y de 96,2\% (127 de 132) en Ivaí. Las especies de parásitos más prevalentes fueron Ascaris, Isospora y Toxocara. Se observó una asociación estadística positiva entre el número de formas parasitarias halladas en los alrededores de cada domicilio y las siguientes variables: la época del año (estación), la existencia de baños domiciliarios y el hallazgo de excremento en el suelo peridomiciliar.

Conclusiones. La gran contaminación del suelo hallada en Faxinal e Ivaí constituye una posible fuente de infección parasitaria e indica que sigue siendo insuficiente el tratamiento de los excrementos de seres humanos y animales.

Microbiología del suelo; parásitos; helmintos; población indígena; parasitosis intestinales; saneamiento básico; Brasil. 